\title{
Evaluation of influence of heavy metals, iodine and fluoride deficiency on the indices of the immune system of rats with gingivitis
}

\author{
N.V. Malko1, O. M. Vynogradova1, O.O. Bandrivska ${ }^{2}$, Y.L. Bandrivsky \\ ${ }^{1}$ Danylo Halytsky Lviv National Medical University; malkonatalj@gmail.com \\ ${ }^{2}$ I. Horbachevsky Ternopil State Medical University
}

\begin{abstract}
The experimental studies on 80 white rats, which were divided into 4 groups of 20 animals each, were conducted to estimate the influence of anthropogenic load in conditions of iodine, fluorine deficit on the state of periodontal tissues in rats. Group 1 - intact animals; group 2 - rats with peroxidation model of gingivitis; group 3 - animals exposed to heavy metals, by adding to the water of inorganic toxicants of cadmium and lead on the background of experimental model of gingivitis; group 4-rats with experimental gingivitis on the background of exposure to heavy metals, iodine deficit, which was caused by the addition of water mercazole and fluoride deficit, which was modeled by keeping animals on a low calorie diet. The analysis of immunological status of experimental animals was estimated for the content of cytokines in blood serum. The content of cytokines (IL-1 $\beta, I L-6, T N F-\alpha, I L-4)$ in blood serum of rats was determined by ELISA using commercial sets ,Vector Best” and transforming growth factor - $\beta 1$ (TGF- $\beta 1$ ) by using the system Quanticine. As a result of researches it is established that minimal immunological changes according to the results of studies were observed in group 2 of animals with modeled gingivitis and a maximal in group 4, where experimental gingivitis was modeled with a combined effect of anthropogenic factors, which in turn emphasizes the importance of xenobiotics in combination with deficit of essential microelements and intensification of the inflammatory process in animals.
\end{abstract}

Key words: gingivitis; rats; blood seru; toxic factors.

\section{INTRODUCTION}

The inflammatory periodontal diseases are the most common pathology in pediatric dentistry $[1,2]$. Thus, from the data of literature, level of child's morbidity by chronic catarrhal gingivitis in Ukraine in the last few years significantly increased [3]. A significant place is occupied by the works of researches, dedicated to the study of influence climatic and geographical conditions on diseases of periodontal tissues, a number of socio-economic factors, that in turn include action of macro- and microelements, salts of heavy metals, which enter organism of child with water, air and food $[1,3,4]$.

At the same time, in scientific literature widely the question of deficit of certain microelements (iodine, fluoride, selenium, iron) comes into question in child's organism and many sided pathogenic changes in a macroorganism, caused by the deficit of essential microelements are studied [4-6].

It is known that $70 \%$ of toxic substances enter the human body from the environment. Therefore, for their large part established the maximal permissible concentrations (MPC) at the insignificant increase of that child's organism can feel the high xenobiotic load and result in negative consequences [2-6].

Taking into account the pathological immunity mechanisms of forming of inflammatory process in periodontium, there is a necessity of deep study of the pathogenesis of periodontal disease. In the development of inflammatory response an important component is the elimination of necrotic masses that have all signs

(C) N.V. Malko, O. M. Vynogradova, O.O. Bandrivska, Y.L. Bandrivsky 
of antigenicity and providing the process of remodeling. The immune system exercises control after realization of these processes. Among the initiators of this response of organism are macrophages, which belong to the obligatory antigen-presented cells. The stimulation in these conditions of immune response assists the synthesis of antibodies, activation of the system of complement, formation of immune complexes with their next destruction that is the important mechanism for maintaining homeostasis [7-9].

Therefore, the study of combined influence of certain xenobiotics as well as deficit of iodine and fluoride on the occurrence of periodontal diseases in children and the development of new corrective schemes of these processes for today are relevant and studied not enough.

The purpose of our work is to assess immunological changes in the blood of animals with gingivitis under the influence of anthropogenic load by conditions of iodine- fluoride deficiency.

\section{METHODS}

The experimental gingivitis in rats was modeled by the transfer of animals aged $30 \pm 5$ days on the peroxide model of gingivitis [10], by adding to the normal ration of per oxygen sunflower oil at a dose of $1 \mathrm{ml}$ per animal during 3 weeks [10]. Everything in the experiment was used 80 rats of line Vistar of the gregarious breeding, with an average weight of $54 \pm 5 \mathrm{~g}$, females and males equally. Depending on the modeling of anthropogenic environmental conditions, the animals were divided into 4 groups of 20 animals in each: 1 (control) - intact rats kept on normal diet vivarium; 2 - rats, which were modeled gingivitis; 3 - rats on peroxidation model of gingivitis, with adding to the water of heavy metals based on their molecular weight $\left(\mathrm{CdCl}_{2}=0.010\right.$ $\left.\mathrm{mg} / \mathrm{l} ; \mathrm{Pb}\left(\mathrm{NO}_{3}\right)_{2}=0.36 \mathrm{mg} / 1\right)[9,11] ; 4$ - rats on peroxidation model of gingivitis + heavy metals + deficit of iodine + deficit of fluoride. The deficit of iodine in organism of rats was induced by adding to the water mercazole, based on 50 $\mathrm{mg} / \mathrm{kg}$ of weight per day during 3 weeks [9].
The deficit of fluoride was modeled by keeping the animals on a low calorie diet with the exception of products containing a lot of fluoride.

The injury and collection of blood were performed under essential anesthesia after 21 days of beginning of experiment [10]. The content of cytokines (IL-1 $\beta$, IL-6, TNF- $\alpha$, IL-4) in blood serum of rats was determined by ELISA using commercial sets ,Vector Best” and transforming growth factor $-\beta 1$ (TGF- $\beta 1$ ) by using the system Quanticine [8].

The studies were carried out with observance of the general rules and provisions of the European convention for the protection of vertebrate animals used for research and other scientific purposes (Strasbourg, 1986), General ethical principles of animal experimentation (Kyiv, 2001). The obtained results were worked out statistically.

\section{RESULTS AND THEIR DISCUSSION}

The study of cytokine profile in blood serum of experimental animals is characterized by increase of proinflammatory cytokines and decrease of anti-inflammatory cytokines under the influence of exogenous factors on the background of modeled gingivitis. It was found that the concentration of IL- 6 in group 1 of animals is $10.55 \pm 0.18 \mathrm{pg} / \mathrm{ml}$. In rats with modeled gingivitis the content of IL- 6 in blood serum increased relatively to the data of intact animals and was $12.17 \pm 0.13 \mathrm{pg} / \mathrm{ml}(\mathrm{P}<0.01)$. The rats of group 3 level of IL-6 in blood serum was $13.54 \pm 0.24$ $\mathrm{pg} / \mathrm{ml}$, that was significantly higher relatively to groups 1 and $2\left(\mathrm{P}<0.01, \mathrm{P}_{1}<0.01\right)$, respectively. The animals of group 4 the concentration of IL-6 in blood serum was maximal and with the value $15.24 \pm 0.24 \mathrm{pg} / \mathrm{ml}$ exceeded data in 1 and 2 study groups $\left(\mathrm{P}<0.01, \mathrm{P}_{1}<0.01\right)$, respectively.

Similar there was the change in the concentration of proinflammatory cytokine TNF- $\alpha$. It was determined the increase of its content in blood serum from $10.60 \pm 0.44 \mathrm{pg} / \mathrm{ml}$ in group 1 of rats to $12.52 \pm 0.24 \mathrm{pg} / \mathrm{ml}$ in 2 experimental group $(\mathrm{P}<0.01)$. The animals of group 3 the con- 
centration of TNF- $\alpha$ increased from $12.98 \pm 0.23$ $\mathrm{pg} / \mathrm{ml}\left(\mathrm{P}<0.01, \mathrm{P}_{1}>0.05\right)$ to the maximal values in group 4 (16.26 $\left.\pm 0.52 \mathrm{pg} / \mathrm{ml}, \mathrm{P}<0.01, \mathrm{P}_{1}<0.01\right)$, where animals were exposed to negative combined action of ecotoxicants on the background of experimental gingivitis.

We have determined that in the first experimental group level of proinflammatory IL-1 $\beta$ was $5.88 \pm 0.46 \mathrm{pg} / \mathrm{ml}$. The concentration of IL$1 \beta$ in animals with experimental gingivitis of 2 group increased to $6.29 \pm 0.41 \mathrm{pg} / \mathrm{ml}(\mathrm{P}>0.05)$, while in group 3 it was $6.84 \pm 0.36 \mathrm{pg} / \mathrm{ml}(\mathrm{P}<0.01$, $\left.\mathrm{P}_{1}>0.05\right)$, in which the modeling of gingivitis was combined with ecotoxical influence of the heavy metals. In the blood serum of animals of the group 4, which were under the influence of heavy metals and deficit of fluoride and iodine on the background of gingivitis there was determined the highest values of concentration of IL-1 $\beta-9.85 \pm 0.31 \mathrm{pg} / \mathrm{ml}\left(\mathrm{P}<0.01, \mathrm{P}_{1}<0.01\right)$.

At the same time, the content of anti-inflammatory cytokines IL- 4 and TGF- $\beta 1$ in animals of the experimental groups decreased. In the intact rats of group 1 the concentration of IL-4 in blood serum was $11.24 \pm 0.42 \mathrm{pg} / \mathrm{ml}$ while this data in animals with experimental gingivitis decreased to $8.46 \pm 0.43 \mathrm{pg} / \mathrm{ml}(\mathrm{P}<0.01)$ and in the 3 study group it decreased to $6.27 \pm 0.41 \mathrm{pg} / \mathrm{ml}(\mathrm{P}<0.01$, $\left.\mathrm{P}_{1}<0.01\right)$. The lowest value of the concentration of IL-4 was noted in the 4 experimental group $4.21 \pm 0.42 \mathrm{pg} / \mathrm{ml}\left(\mathrm{P}<0.01, \mathrm{P}_{1}<0.01\right)$.

The concentration of anti-inflammatory TGF- $\beta 1$ in blood serum in intact animals was $8.25 \pm 0.4 \mathrm{pg} / \mathrm{ml}$ and it decreased to $6.28 \pm 0.41$ $\mathrm{pg} / \mathrm{ml}(\mathrm{P}<0.01)$ in the 2 group of rats. The minimal values of the content of TGF- $\beta 1$ were in the 3 and 4 experimental groups, where the concentration of TGF- $\beta 1$ was $4.46 \pm 0.40 \mathrm{pg} / \mathrm{ml}$ $\left(\mathrm{P}<0.01, \mathrm{P}_{1}<0.01\right)$ and $3.12 \pm 0.41 \mathrm{pg} / \mathrm{ml}(\mathrm{P}<0.01$, $\mathrm{P}_{1}<0.01$ ), respectively (Fig.1).

\section{CONCLUSIONS}

As a result of conducted studies, it was established that minimal immunological changes were marked in the 2 group of animals with the modeled gingivitis while in the 4 group of animals, where gingivitis was experimentally modeled with the combined action of anthropogenic factors the changes were maximal. These results underline the importance of xenobiotic combined with the deficit of essential microelements in the intensification of inflammatory process in organism of animals.

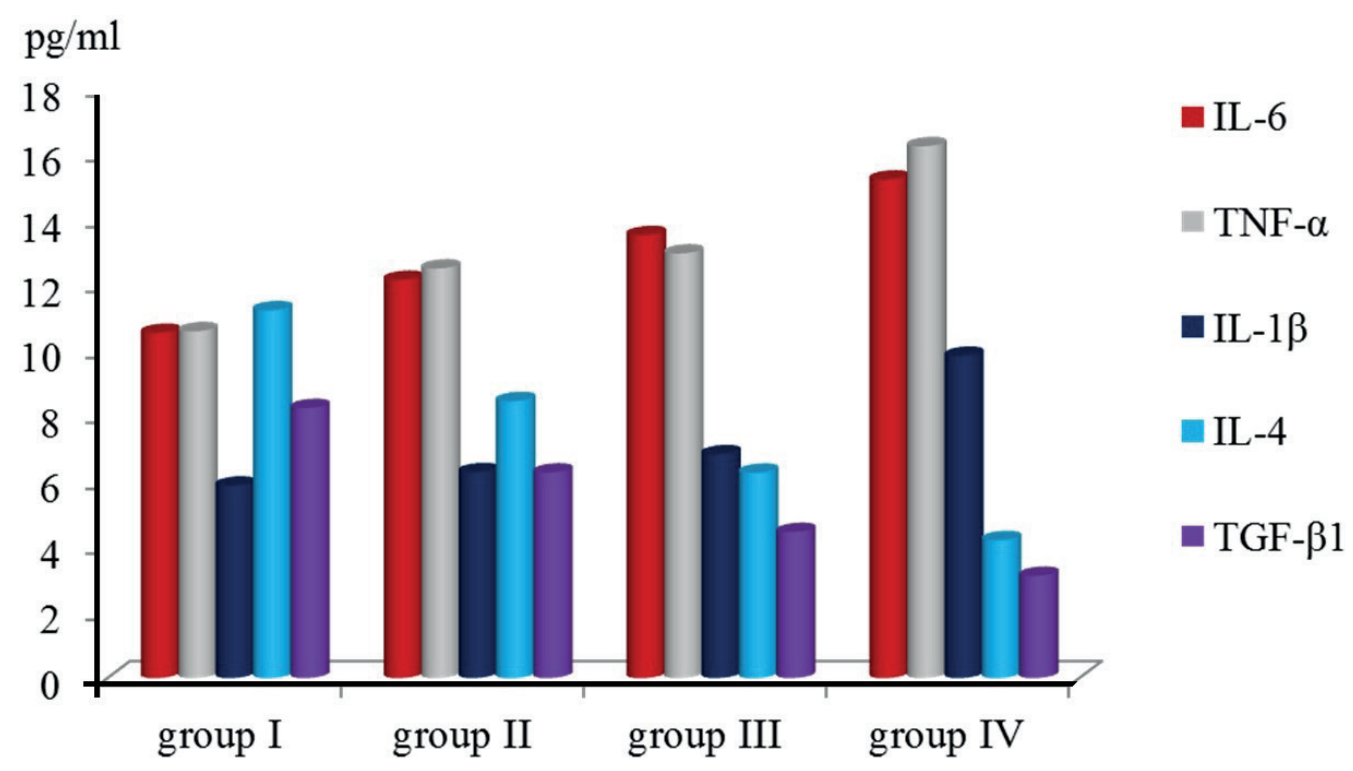

Fig. 1. The content of cytokines in blood serum of experimental rats 
The author of this study, N.V. Malko, O.M. Vynogradova, O.O. Bandrivska, Y.L. Bandrivsky, confirm that the research and publication of the results were not associated with any conflicts regarding commercial or financial relations, relations with organizations and/or individuals who may have been related to the study, and interrelations of co-authors of the article.

\section{Н.В. Малко ${ }^{1}$, О.М. Виноградова ${ }^{1}$, О.О. Бандрівська², Ю.Л. Бандрівський ${ }^{2}$ \\ ОЦІКАА ВПЛИВУ ВАЖКИХ МЕТАЛІВ, ЙОД-, ФТОРДЕФЦЦИТУ НА ПОКАЗНИКИ ІМУН- НОЇ СИСТЕМИ ЩУРІВ ПРИ ГІНГІВІТІ}

Для оцінки впливу важких металів, йод-, фтордефіциту на стан тканин пародонта щурів проведено експериментальні дослідження на 80 білих тваринах, які були поділені на 4 групи по 20 тварин у кожній. До 1-ї групи ввійшли інтактні тварини; 2-ї - тварини 3 гінгівітом; 3-ї - тварини, що зазнавали впливу важких металів 3 додаванням до води кадмію та свинцю на тлі моделі гінгівіту; 4-і - тварини 3 гінгівітом на фоні впливу важких металів, йод-, фтордефіциту. Аналіз імунологічного статусу тварин оцінювали за вмістом цитокінів у сироватці крові. Вміст інтерлейкінів (IL) IL-1 $\beta$, IL-6, IL-4, фактора некрозу пухлин $\alpha$ (ФНП- $\alpha$ ), досліджували за допомогою імуноферментного аналізу 3 використанням комерційних наборів «Вектор Бест», а трансформуючий фактор росту $\beta 1$ (ТФР- $\beta 1)$ - системи «Quanticine». Встановлено, що мінімальні імунологічні зміни за результатами досліджень, відзначались у 2-й групі тварин, а максимальні - у 4-й групі, що супроводжувалося зниженням вмісту протизапальних цитокінів - IL-4 та ТФР- $\beta 1$ в 2,6 раза на тлі підвищення вмісту прозапальних цитокінів IL-6 у 1,4 раза, ФНП- $\alpha$ у 1,5 раза, IL-1 $\beta$ у 1,7 раза, що, у свою чергу, підкреслює значимість ксенобіотиків у поєднанні з дефіцитом ессенціальних мікроелементів, у інтенсифікації запального процесу в організмі тварин. Ключові слова: гінгівіт; щури; сироватка крові; токсичні фактори.

${ }^{1}$ Львіський національний медичний університет імені Данила Галииького;

${ }^{2}$ Тернопільський державний медичний університет імені I.Я. Горбачевського

Н.В. Малко ${ }^{1}$, Е.Н. Виноградова ${ }^{1}$, О.О. Бандривская ${ }^{2}$, Ю.Л. Бандривский ${ }^{2}$

ОЦЕНКА ВЛИЯНИЯ ТЯЖЕЛЫХ МЕТАЛЛОВ, ЙОД-, ФТОРДЕФИЦИТА НА ПОКАЗАТЕЛИ ИММУННОЙ СИСТЕМЫ КРЫС ПРИ ГИНГИВИТЕ

Для оценки влияния тяжелых металлов, йод-, фторде- фицита на состояние тканей пародонта крыс проведены экспериментальные исследования на 80 белых животных, которые были разделены на 4 группы по 20 животных в каждой. В 1-ю группу вошли интактные животные; 2-ю животные с гингивитом; 3-ю - животные, подвергавшиеся воздействию тяжелых металлов с добавлением к воде кадмия и свинца на фоне модели гингивита; 4-ю - животные с гингивитом на фоне влияния тяжелых металлов, йод-, фтордефицита. Анализ иммунологического статуса животных оценивали по содержанию цитокинов в сыворотке крови. Содержание интерлейкинов (IL) IL-1 $\beta$, IL-6, IL-4, фактора некроза опухолей $\alpha$ (ФНО- $\alpha)$, исследовали с помощью иммуноферментного анализа с использованием коммерческих наборов «Вектор Бест», а трансформирующий фактор роста $\beta 1$ (ТФР- $\beta 1)$ - системы «Quanticine». Установлено, что минимальные иммунологические изменения по результатам исследований, отмечались во 2-й группе животных, а максимальные - в 4-й группе, что сопровождалось снижением сожержания противовоспалительных цитокинов - IL-4 и ТФР- $\beta 1$ в 2,6 раза на фоне повышения содержания провоспалительных цитокинов IL-6 в 1,4 раза, ФНО- $\alpha$ в 1,5 раза, IL- $1 \beta$ в 1,7 раза, что, в свою очередь, подчеркивает значимость ксенобиотиков в сочетании с дефицитом эссенциальных микроэлементов, в интенсификации воспалительного процесса в организме животных.

Ключевые слова: гингивит; крысы; сыворотка крови; токсические факторы.

\section{REFERENCES}

1. Ostapko OI. The influence of environmental factors on the level of dental health of Ukrainian children. Bull NMU OO. Bogomolets, 2007: 162-4. [Ukrainian].

2. Savychuk OV, Nemyrovych YP, Golibyeva IM. Clinical efficacy of complex prevention of caries and gingivitis in children population of ecologically adverse regions. News Dent (3), 2007: 82-4. [Ukrainian].

3. Leus PO. Pilot project: „Optimization system of dental care to children population”. Bull Dent (2), 2010: 14146. [Belorussia].

4. Lozovyi MP, Nikitina AV, Kuzmenko LI. The results of monitoring study the effects of air quality on the health of the child population. Sci Bull NMU OO. Bogomolets (27), 2010: 143-45. [Ukrainian].

5. Kryuchenko NV. The presence of fluoride in underground waters of Ukraine and the diseases associated with it. Search Env Geochem (1), 2001: 9-13. [Ukrainian].

6. Petrovska M. The health of the population in Lviv region as a result of reaction to changes in the environment. Bull Lviv Univ Ser Geogr. 39, 2011: 267-77. [Ukrainian].

7. Khaitov RM. Clinical allergology: a guide for practical doctors. Moscow: Medpresinform, 2002: 624. [Russian].

8. Lapovets LE, Lutsyk BD, Akimova VM, Lebed GB, Zubchenko SO. Manual of laboratory immunology. Lviv, 2014: 300. [Ukrainian]. 
9. Yakovlev MY. „Endotoxin aggression” as premorbidity or a universal factor of pathogenesis of diseases of humans and animals. Suc Mod Biochem (1), 2003: 31-40. [Ukrainian].

10. Levytsky AP, Denga OV, Makarenko OA, Khromagina LN. Experimental methods of playback of gingivitis. Odessa, 2013: 14. [Ukrainian].

11. Severynovska AV, Grygorova NA, Zaychenko OY, Ry- balchenko VK. The influence of eco-pathogenic factors of environment on antioxidant protection system in the departments of cerebrum of rats. Fiziol Zh 52 (6), 2006: 85-92. [Ukrainian].

12. Vynogradov VM, Katkova EB, Mukhin EA. Pharmacology with the recipe, 5 th ed. Rev. Sankt Peterburg, Spetslit. 2009: 864. [Russian]. 